\title{
Supraglacial debris cover assessment in the Caucasus Mountains, 1986-2000-2014
}

\author{
Levan G. Tielidze ${ }^{1,5}$, Roger D. Wheate ${ }^{2}$, Stanislav S. Kutuzov ${ }^{3}$, Kate Doyle ${ }^{4}$, Ivan I. Lavrentiev ${ }^{3}$
}

${ }^{1}$ Department of Geomorphology, Vakhushti Bagrationi Institute of Geography, Ivane Javakhishvili Tbilisi State University, Tamarashvili st., Tbilisi, Georgia, 0177

${ }^{2}$ Natural Resources and Environmental Studies, University of Northern British Columbia, 3333 University Way, Prince George, BC, Canada, V2N 4Z9

$10{ }^{3}$ Department of Glaciology, Institute of Geography of the Russian Academy of Sciences, 29 Staromonetniy Pereulok, Moscow, Russia 119017

${ }^{4}$ Institute of Cartography, Technical University of Dresden, 01069, Dresden, Germany

${ }^{5}$ Department of Earth Sciences, Georgian National Academy of Sciences, 52 Rustaveli Ave., Tbilisi, Georgia, 0108

15

Correspondence to: Levan G. Tielidze (levan.tielidze@ tsu.ge)

\begin{abstract}
Surpaglacial debris cover plays an increasingly important role impacting on glacier ablation, while there have been limited recent studies for the assessment of debris covered glaciers in the Greater Caucasus mountains. We selected 559 glaciers according to the sections and macroslopes in the Greater Caucasus main watershed range and the Elbrus massif to assess supraglacial debris cover (SDC) for the years 1986, 2000 and 2014. Landsat (Landsat 5 TM, Landsat 7 ETM+, Landsat $8 \mathrm{OLI}$ ) and SPOT satellite imagery were analysed to generate glacier outlines using manual and semi-automated methods, along with slope information from a Digital Elevation Model. The study shows there is greater SDC area on the northern than the southern macroslope, and more in the eastern section than the western and central. In 1986-2000-2014, the SDC area increased from $6.4 \%-8.2 \%-19.4 \%$ on the northern macroslope (apart from the eastern Greater Caucasus section), while on the southern macroslope, SDC increased from 4.0\%-4.9\%-9.2\%. Overall, debris covered glacier numbers increased from 122-143-172 (1986-2000-2014) for 559 selected glaciers. Despite the total glacier area decrease, the SDC glacier area and numbers increased as a function of slope inclination, aspect, glacier morphological type, Little Ice Age (LIA) moraines, rock structure and elevation. The datasets are available for public download at doi.pangaea.de/10.1594/PANGAEA.880147.
\end{abstract}




\section{Introduction}

Mountain glaciers are an integral part of the cryosphere and a vital component of Earth's natural systems, serving as sensitive indicators of climate change. Glaciers around the world have been experiencing recession at varying intensities and offer explicit evidence of global warming (Haeberli, et al., 1999; Oerlemans, 2005; Paul et al., 2007). Due to their remoteness, size and inaccessible nature, remotely sensed data are likely the most effective tool for regular mapping of mountain glaciers in a comprehensive manner.

Glacier surfaces can be either clean or debris-covered, where the sources and quantity of debris are variable. The prime activities which cause debris cover on glaciers are rock fall and slides, and mass movements from adjacent mountain slopes, with other sources including pollutants, salts and micro-organisms from sea spray, volcanic eruptions and wind-blown dust (Benn and Evans, 1998). Snow and rock-ice avalanching are also an important mechanism for transporting debris onto glacier surfaces (Raina and Srivastava, 2008), especially in high mountain environments such as the Greater Caucasus, where large quantities of snow can accumulate on unstable slopes (Kaldani and Salukbadze, 2015). When these snow or rock-ice slopes collapse, they can result in large and destructive avalanches, enough to detach debris from underlying rock surfaces, e.g. the Devdoraki Glacier rock-ice avalanche in Georgia in May 2014 (Tielidze, 2017a).

Generally, debris covered glaciers characterize most mountain regions of the world (Scherler et al., 2011) and are an inseparable component of glacial systems in mountain environments (Biddle, 2015). Supraglacial debris cover (SDC) obscures glacier ice extents, challenging accurate glacier mapping (Shukla et al., 2010a; Veettil, 2012). Additionally, debris cover on the tongues of mountain glaciers affects melt rates, increasing rates of ablation in cases of thin debris cover, or decreasing ablation under thick debris cover (Brock et al. 2010). Changes in glacial environments in mountain regions, especially with regard to debris cover, can augment the potential for glacial hazards (Benn et al., 2012). For some regions where the local population is dependent on glacial meltwater for water supplies, exact evaluation of glacial hydrology is important to ensure the sustainable use of water resources (Baraer et al., 2012). The difficulty of such investigations is associated with poor knowledge of the large-scale spatial distribution of the thickness and properties of debris, since field measurements of thickness and properties of the debris layer have practical difficulties on a large scale, and methods for satellite mapping of supraglacial debris remain in development (Foster et al., 2012; Zhang et al., 2016).

Europe's highest mountain system - the Greater Caucasus - contains over 2000 glaciers, with a total area of $1121 \pm 30 \mathrm{~km}^{2}$ (Kutuzov et al., 2015). The Greater Caucasus SDC is an important control for ice ablation, as it is similarly in many other glaciated areas (Lambrecht et al., 2011) and has been identified as a key player in glacier mass balance (Popovnin and Rozova, 2002). In addition, in some cases SDC and proglacial lakes are directly related to glacial hazards. Therefore, it is necessary to take into account the SDC and periglacial debris cover on the outside 
of the glacier margin, when assessing temporal change in this region. Debris cover becomes especially important in understanding the complex relation between climate change and glacier accumulation and ablation.

\section{Study area and previous studies}

The Greater Caucasus can be divided into three parts: Western, Central, and Eastern. Their borders run near the meridians of Mount Elbrus (5642 m) and Mount Kazbegi (5047 m) (Tielidze, 2017b). At the same time, the terms Northern and Southern Caucasus are frequently used to refer to the corresponding macroslopes of the Greater Caucasus range (Solomina et al., 2016).

As a result of variations in climate conditions, glacier character and rock structure (Tielidze, 2017a), both northern and southern macroslopes were selected for the western and central Greater Caucasus, as they contain most of the glaciated areas. However, for the eastern section, only the northern macroslope was selected as glaciers are almost non-existent in the south (Fig. 1).

In the western Greater Caucasus, 145 glaciers in the Kuban River basin (northern slope) and 78 glaciers in Kodori River basin (southern slope) were selected (Fig. 1a); 173 glaciers in the Baksan, Chegem, Cherek (northern slope) and 112 glaciers in the Enguri River basin (southern slope) were selected for the central Greater Caucasus (Fig. 1b); and 130 glaciers in the Tergi (Terek) headwaters, Sunja Right tributaries and Sulak river basins were selected in the eastern Greater Caucasus (Fig. 1c). In addition, 21 glaciers on the Elbrus massif were selected as an area of less debris cover (Fig. 1d). The size of the largest glacier selected was $37.5 \mathrm{~km}^{2}$ and the smallest $0.01 \mathrm{~km}^{2}$.

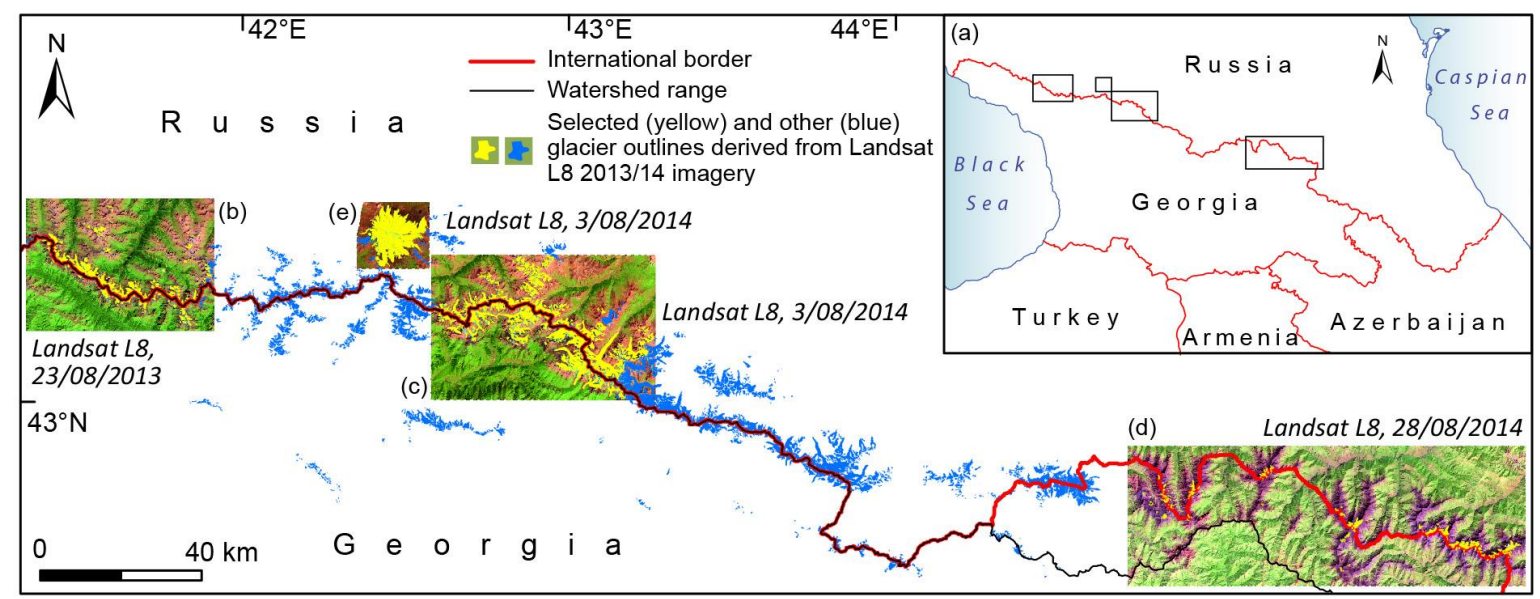

Figure 1. Investigated area (a) and selected glaciers in sections - western Greater Caucasus (b); central Greater Caucasus (c); eastern Greater Caucasus (d); the Elbrus (e). 
Studies conducted on SDC assessment in the Greater Caucasus have usually focused on a limited study area. Stokes et al. (2006), used Landsat TM and ETM+ imagery to assess Greater Caucasus glaciers, and reported that the debris cover has increased concurrently with glacier reduction in the central Greater Caucasus between 1985-2000. Stokes et al. (2007) calculated SDC ranges from $<5 \%$ to $>25 \%$ on individual glaciers in the central Greater Caucasus for the period 1985-2000. Based on Corona (1971) and Spot (2006) imagery, Lambrecht et al. (2011), selected two small river basins in the central Greater Caucasus - Adyl-su on the northern macroslope and Zopkhito on the southern. For the Adyl-su basin glaciers, the debris cover area was $\sim 16 \%$ for the period 1971-1991, increasing to $23 \%$ between 1991 and 2006. For the Zopkhito basin glaciers, the debris cover increase was lower in the same period (from $6.2 \%$ to $8.1 \%$ ). Popovnin et al. (2015), reported a debris cover increase from $2 \%$ to $13 \%$ between 1968-2010, based on direct field monitoring for the Djankuat glaciers (northern macroslope).

This research further aims to compare glacier mapping using manual and semi-automated methods to assess the SDC change across a larger area than previous studies according to the western, central and eastern Greater Caucasus over the last 30 years.

\section{Data and methods}

\subsection{Datasets}

Landsat 5 TM imagery from 1985/86 and Landsat 8 OLI imagery from 2013/14 with manually mapped glacier outlines for the Greater Caucasus' latest glacier inventory (Tielidze and Wheate, 2017) were used in this study. In addition, Landsat 7 ETM+ imagery from 2000 were downloaded from the Earthexplorer website (http://earthexplorer.usgs.gov/) (Table 1).

Paul et al. (2013) suggested that high resolution imagery and manual delineation do not necessarily provide better accuracy, but they certainly provide a better understanding of the difficulties in mapping debris covered glaciers. We also used high resolution $(1.5 \mathrm{~m})$ satellite image of 2016 (SPOT) for manual correction of glacier outlines on the eastern slopes of Elbrus. Additionally, the results of airborne Ground Penetrating Radar (GPR) survey conducted on 20132014 at Elbrus were included (Kutuzov et al., 2015; Farinotti et al., 2017). All imagery was captured at the end of the summer season from the $28^{\text {rd }}$ of July to the $12^{\text {th }}$ of September.

The ASTER GDEM, v2 (2011) was used to extract slope information for the Greater Caucasus. The vertical and horizontal accuracy of the GDEM are $\sim 20 \mathrm{~m}$ and $\sim 30 \mathrm{~m}$, respectively. We decided to use the ASTER GDEM instead of the Shuttle Radar Topography Mission (SRTM) DEM considering the higher resolution (30 m and $90 \mathrm{~m}$, respectively) and the large data gaps of the SRTM DEM in this study area; the ASTER GDEM has been shown to have fewer voids in mountain terrains (Frey et al., 2012). 
Table 1. Satellite images used in this study.

\begin{tabular}{|r|r|r|r|r|r|}
\hline Date & $\begin{array}{r}\text { UTM } \\
\text { zone }\end{array}$ & Type of imagery & Region/Section & Resolution & Scene ID \\
\hline $10 / 08 / 1985$ & $37 \mathrm{~N}$ & Landsat 5 & Western Greater Caucasus & $30 \mathrm{~m}$ & LT51720301985222XXX04 \\
\hline $06 / 08 / 1986$ & $38 \mathrm{~N}$ & Landsat 5 & Central Greater Caucasus & $30 \mathrm{~m}$ & LT51710301986218XXX02 \\
\hline $31 / 08 / 1986$ & $38 \mathrm{~N}$ & Landsat 5 & Eastern Greater Caucasus & $30 \mathrm{~m}$ & LT51700301986243XXX03 \\
\hline $12 / 09 / 2000$ & $37 \mathrm{~N}$ & Landsat 7 ETM+ & Western Greater Caucasus & $15 / 30 \mathrm{~m}$ & LE71720302000256SGS00 \\
\hline $05 / 09 / 2000$ & $38 \mathrm{~N}$ & Landsat 7 ETM+ & Central Greater Caucasus & $15 / 30 \mathrm{~m}$ & LE71710302000249SGS00 \\
\hline $28 / 07 / 2000$ & $38 \mathrm{~N}$ & Landsat 7 ETM+ & Eastern Greater Caucasus & $15 / 30 \mathrm{~m}$ & LE17003020000728SGS00 \\
\hline $23 / 08 / 2013$ & $37 \mathrm{~N}$ & Landsat 8 & Western Greater Caucasus & $15 / 30 \mathrm{~m}$ & LC81720302013235LGN00 \\
\hline $03 / 08 / 2014$ & $38 \mathrm{~N}$ & Landsat 8 & Central Greater Caucasus & $15 / 30 \mathrm{~m}$ & LC81710302014215LGN00 \\
\hline $28 / 08 / 2014$ & $38 \mathrm{~N}$ & Landsat 8 & Eastern Greater Caucasus & $15 / 30 \mathrm{~m}$ & LC81700302014240LGN00 \\
\hline $20 / 08 / 2016$ & $37 \mathrm{~N}$ & SPOT-7 & Elbrus & $1.5 \mathrm{~m}$ & DS_SPOT7201608200751063 \\
\hline
\end{tabular}

\subsection{Thermal/Near-IR/Mid-IR band ratio methodology}

There are several methods for mapping glaciers with debris cover assessment, which can be grouped into categories, as follows: manual delineation (Paul et al. 2002), semi-automated delineation (Paul and Kaab, 2005; Andreassen et al., 2008; Bolch et al., 2010), multispectral image classification (Bishop et al.,1999), thermal properties (Ranzi et al. 2004), geomorphometric parameters (Bishop et al., 2001; Bolch and Kamp 2006) and a combination of the above methods (Paul et al., 2004; Shukla et al., 2010a; Bhambri et al., 2011). All these methods have difficulty when used for (a) mapping debris-covered glaciers covered by a thick debris layer and/or (b) mapping debris-covered glaciers when the glacier terminus region transition to the unglaciated region is gentle (Alifu et al., 2015).

Alifu et al. (2015) devised a compound ratio method to reduce these errors, dividing digital number (DN) values of the thermal band (band 6) by the standard red/Mid-Infrared ratio, for Landsat TM and ETM+ [Ratio = Band $6 /($ Band $4 /$ Band 5) $]$, and applying a threshold value of 2.0.

This approach characterizes low values of supraglacial debris in the band 4 / band 5 ratio and enables separation from periglacial debris when band 6 is divided by this result. This method was tested for TM data, and three different combinations were attempted for OLI imagery (23/08/2013) using either of the two thermal bands as well as an average of both bands: on Landsat 8, the thermal wavelengths cover two bands from the Thermal Infrared Sensor (TIRS, bands 10 and 11) rather than one (Band 6) in TM.

\subsection{Geomorphometric parameters methodology}

Another semi-automated classification using geomorphometric parameters was tested for OLI imagery (23/08/2013) in order to improve the classification of debris-covered ice, and compare and contrast results with manual outlines and Alifu et al. (2015) methodology. Some 
authors (e.g. Racoviteanu et al. 2014; Racoviteanu and Williams, 2012) suggest the use of a Digital Surface Model (DSM) or DEM to improve classification using slope and texture parameters and integrate with proximity analysis to extract debris covered ice. Texture parameters from Racoviteanu and Williams (2012) were used with appropriate thresholds chosen after suitable querying. These parameters were entropy (measure of uniformity), homogeneity (measure of similarity) and variance (measure of variability, the opposite of homogeneity). All these parameters are based on second-order statistics computed from a gray level co-occurrence matrix, which calculates how often pairs of pixels occur in a spatial relationship. Slope and elevation were also extracted from the DSM to exclude lower lying bare rock. Following the standard application of a Red/Mid-Infrared ratio (OLI bands 4/6), a buffer distance was created around the band ratio image (i.e. clean ice), different distances were tested to find the best balance between debris identification and bare rock exclusion: $500 \mathrm{~m}$ was found to be the most applicable for the given date and region. This was then combined with the previous clean glacier ice ratio image to form glacier outlines with debris. To remove excess misclassified polygons manual adjustments were performed using the most recent Caucasus glacier inventory for authentication (Tielidze and Wheate, 2017) and by exporting the outlines to KML and verifying them with 3D topography in Google Earth. The work flow chart is shown in Figure 2, incorporating the recently available ALOS 30 m Global DSM.

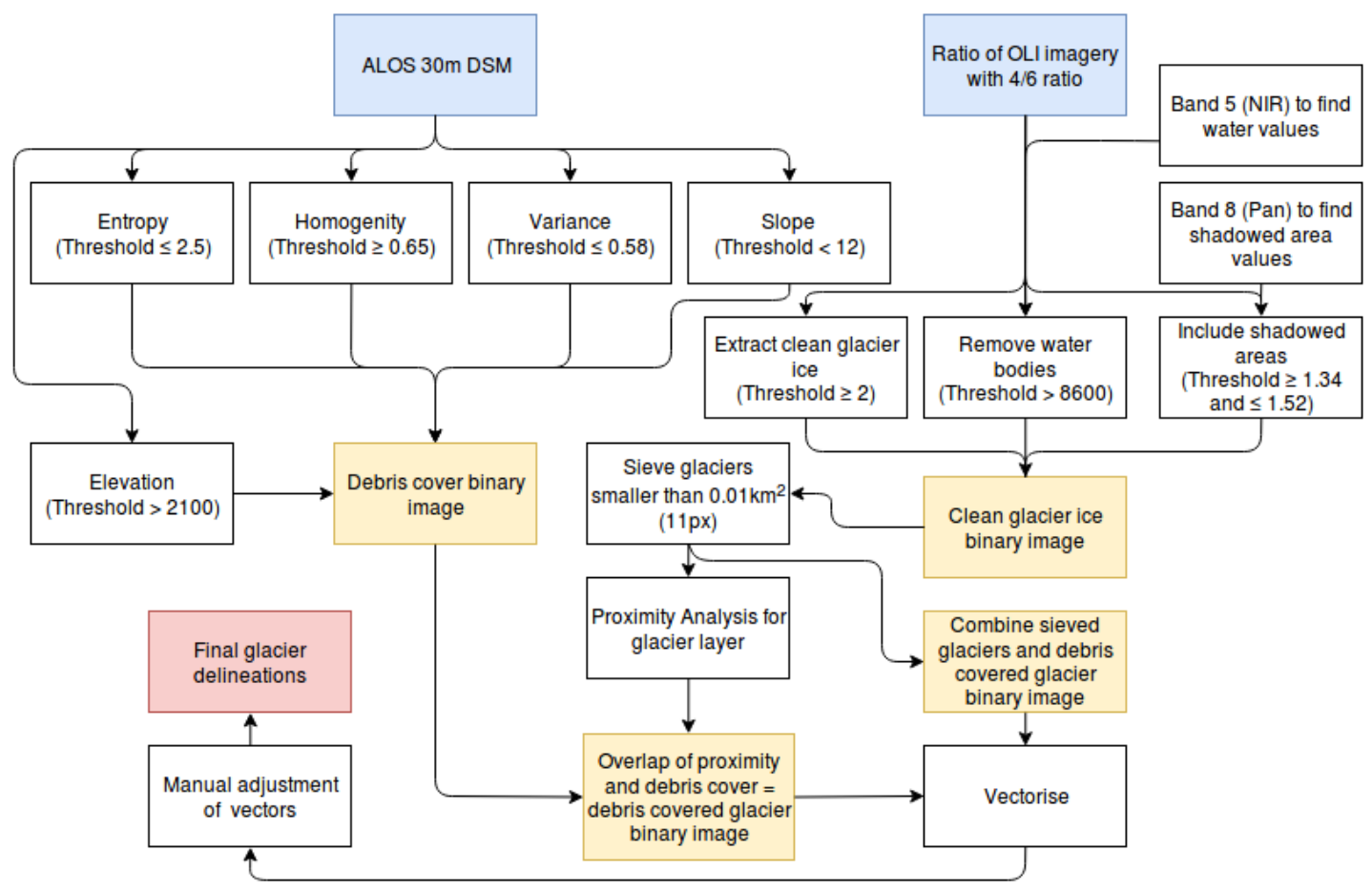

Figure 2. Semi-automated classification methodology using geomorphometric parameters. 
Even with manual adjustments, the semi-automated method with geometric parameters (Fig. 2) is usually faster than drawing manual extents. Tiwari et al. (2016) indicate the speed of semiautomated methods on a sample area in the Himalayas (two glaciers with differing debris cover) using a DSM to calculate geomorphometric parameters (slope and curvature). The average processing time for the semi-automated method was 3-4 hours while the manual method could take 5-20 hours depending on knowledge and experience. Drawing manual outlines can be arduous and time-consuming (Paul, 2000), particularly if future glacier analysis were to be undertaken on a regional scale. However, problems exist between the accuracy of semi-automated methods versus manual delineations. The semi-automated method performs well with clean glacier ice, however debris covered glacier identification is fragmented.

\subsection{Manual extents compared to Red/Mid-IR ratio methodology}

When discussing semi-automated methods, perhaps the most widely used are simple bandratios which are effective in finding areas of clean ice, and for regions with many glaciers provides a fairly robust, fast and often more accurate estimate of glacier area than other, more complex, methods (Paul, et al., 2016).

After the creation of clean glacier outlines using the OLI 4/6 or TM 3/5 ratio, extra polygons (late lying snow, shadows) were deleted and corrected relative to the 1986, 2000 and 2014 manual outlines (except for the debris covered area) from the latest glacier inventory (Tielidze and Wheate, 2017).

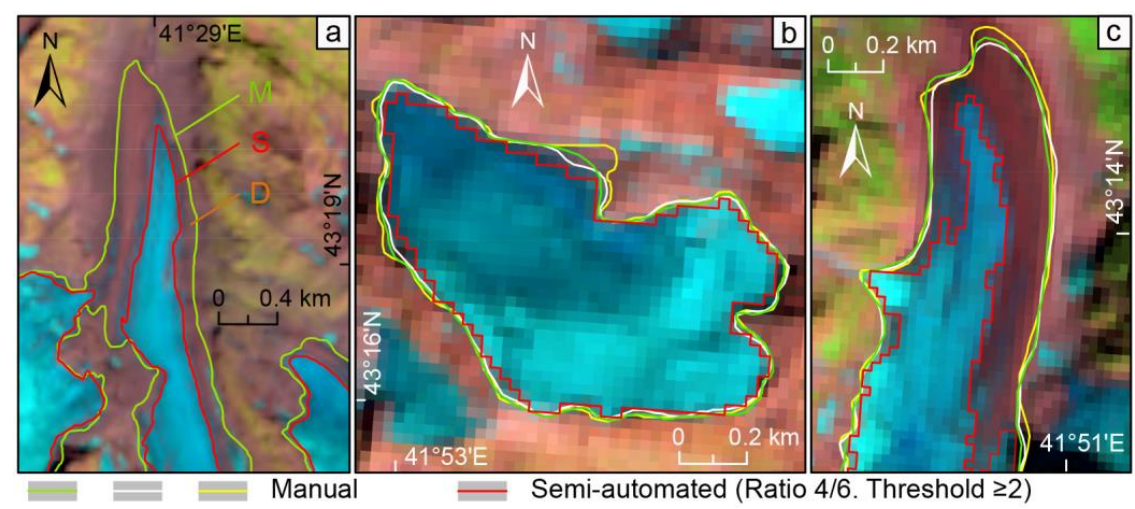

Figure 3. (a) Debris cover - D assessment attempt with comparison of Manually - M and Semi-automated - S (ratio OLI 4/6) methods. Examples from the multiple digitizations for debris free (b) and debris covered (c) glaciers (bands 654 as RGB) using the OLI scene performed by different analysts (coloured lines). Pixel size is $30 \mathrm{~m}$. Landsat 8 OLI, 23/08/2013.

This semi-automated technique might be faster (Tiwari et al., 2016) than manual delineation at visualizing the bare-ice extent, but it was important to manually correct the semi-automated 
outlines of up-glacier boundaries of the debris-covered ice as accurately as possible in order to assess subtle changes in the extent over time (e.g. the emergence of thin medial moraines may have been beyond the resolution of automated techniques).

Manual outlines are generally deemed the most accurate approach to glacier mapping, and due to the local knowledge and recent nature of Tieldize and Wheate's (2017) outlines, these were used to correct the band-ratio results, along with the panchromatic band for a more accurate result. Additionally, the band ratio delineations were compared with manual outlines in order to see which is preferable for glacier delineation.

As a result of the band ratio methods success in clean ice identification, a simple approach was tested to assess the debris cover area; with debris cover area being the difference between the manual and semi-automated extents (Fig 3a).

\subsection{Error estimation}

The sources of glacier delineation errors can be divided into three classes (Raup et al., 2007; Paul and Andreassen, 2009): a) technical errors, b) interpretation errors and c) methodological errors. Technical errors can be mostly ignored if the satellite image has been accurately orthorectified, which was the case for Landsat images provided by USGS (e.g. Tielidze, 2016; Tielidze and Wheate, 2017). Interpretation errors mostly depend on how 'glacier' is defined for the purposes of inventory compilation, and thus are difficult to evaluate. Methodological errors were largely decided by the resolution of the Landsat images, and the skills of the inventory compilers which also cannot accurately be assessed (Pfeffer et al., 2014).

The glacier area error tends to be inversely proportional to the length of the glacier margin (Pfeffer et al., 2014), so it depends on the size of the glacier (larger glaciers mostly have longer margins). In this sense, the area error assessed by glacier buffers (Granshaw and Fountain, 2006; Bolch et al., 2010) is rational because it accounts for the length of the glacier perimeter. For debris-free glacier ice, DeBeer and Sharp (2007) suggested that line placement uncertainty is unlikely to be larger than the resolution of the imagery, i.e. $\pm 15-30 \mathrm{~m}$ for Landsat imagery, while Frey et al. (2012) used the width of a half pixel. A buffer with a conservative width of one pixel was created along the glacier outlines and the uncertainty term was calculated as an average ratio between the original glacier areas and the areas with a buffer increment; for the 1986 and 2000 images we used a buffer equal to the resolution of the data $(15 / 30 \mathrm{~m})$ and a similar buffer for the 2014 glacier extents. This generated an average uncertainty of the mapped glacier area of $4.2 \%$ for $1986,4.3 \%$ for 2000 and $4.4 \%$ for 2014.

The buffer width, however, is critical to the resultant glacier area error (Guo et al., 2015); following Paul et al. (2013) we manually digitized multiple (3) times, six different size glaciers in the western, central and eastern Greater Caucasus to estimate 1986, 2000 and 2014 glacier area error (Fig. 3b, c). For debris covered glaciers, the Normalised Standard Deviation (NSD - based on delineations by multiple digitalization divided by the mean glacier area for all manual outlines) 
was $6.2 \%$ and the difference between the manually and automatically derived area was $12.3 \%$. For debris-free glaciers the NSD was $5.9 \%$ and the difference between the manually and automatically derived area was $4.7 \%$.

The GPR survey of 2014 has shown the existence of large debris covered parts of glacier tongues on the eastern slopes of the Elbrus massif which were previously not included in the glacier area (Shahgedanova et al., 2014). High resolution SPOT 7 imagery confirmed the complicated geomorphology and was used for additional corrections of the debris covered area. Accuracy assessment of debris-covered glacier outlines are challenging without more ground truthing (Frey et al., 2012) and local uncertainty values can be as high as five pixels or $\pm 150 \mathrm{~m}$ (Paul et al. 2013). However given the large total glacier area of the Elbrus massif and a small relative SDC area, we used an error estimation of one pixel buffer (15-30m).

\section{Results and discussion}

\subsection{Supraglacial debris cover (SDC) assessment using Thermal/Near-IR/Mid-IR band ratio methodology}

Alifu et al. (2015) created a ratio which seemed useful in identifying a larger extent of debris cover than using a simple ratio with TM imagery (Fig. 4a-c), but when applied to OLI imagery the results were less satisfactory (Fig. 4d).
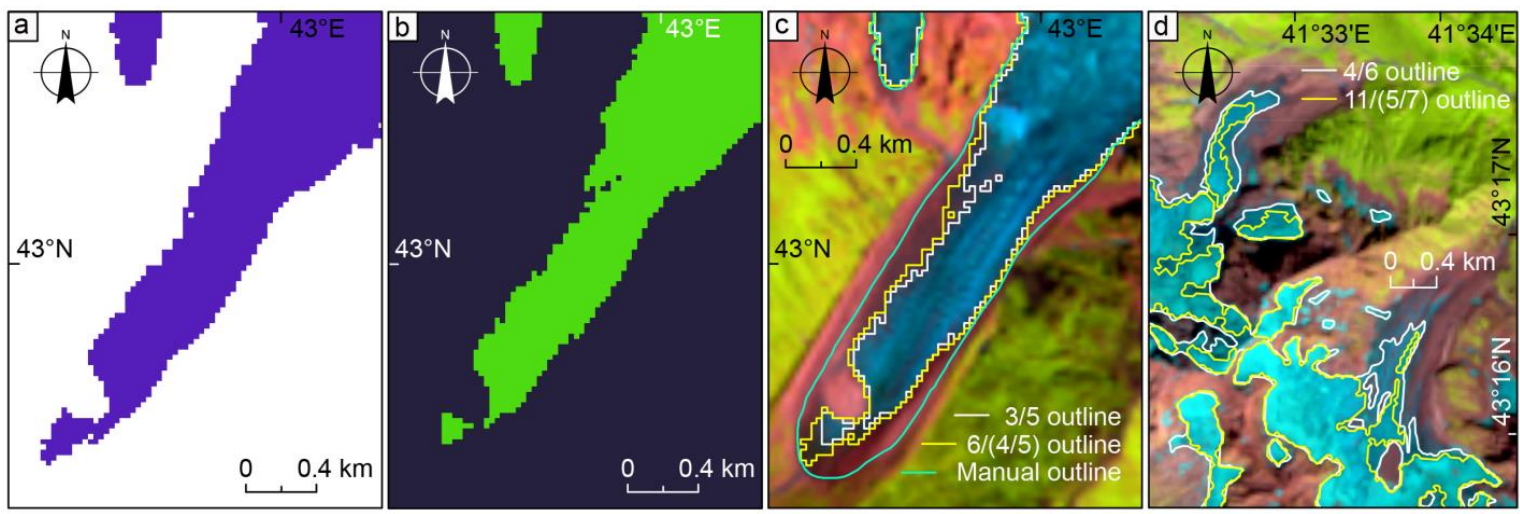

Figure 4. Comparison of (a) 6TM / (4TM / 5TM) (Alifu et al., 2015) raster with (b) 3TM / 5TM raster for the (c) Adishi Glacier 6/08/1986 Landsat 5 TM imagery (central Greater Caucasus); (d) Comparison between the Alifu et al. (2015) methodology and a regular 4/6 band ratio on a Landsat 8 OLI, 23/08/2013, western Greater Caucasus.

The percentage of glacier cover (including debris covered glacier) identified with the Alifu et al. (2015) method was less than the $4 / 6$ ratio and a large amount of glacier was misidentified. When compared to manual delineations, the OLI ratios overestimated the non-glacier areas by an average of $3.9 \%$, versus $2.8 \%$ when using only the $4 / 6$ ratio. Users accuracy (i.e. the reliability; 
the number of correctly classified pixels according to ground truth, in this case the manual outlines) was calculated between the manual and Alifu et al. (2015) classified glacier outlines, with the result being higher for the $4 / 6$ method at $69.2 \%$ compared to the Alifu et al. method at only $59.1 \%$. Therefore, the Alifu et al. methodology to identify debris covered ice in the Greater Caucasus cannot be considered robust for OLI imagery, and unsuitable for extended time series.

\subsection{SDC assessment using the integrating geomorphometric parameters methodology}

More debris cover was correctly identified by integrating geomorphometric parameters than solely using the 4/6 ratio, although mapped glacier tongues remained incomplete; in addition, over-classification often occurred on areas of bare rock, characterized as debris covered ice (Fig. 5a). The benefit of local knowledge and GPS points can be seen in Figures $5 \mathrm{~b}$ and $5 \mathrm{c}$ where both cloud and shadow hidden areas of glacier cover which were recognized in the Tielidze \& Wheate (2017) outlines as a result of field measurements. Compared with a simple 4/6 ratio and the Alifu et al. (2015) method, this integrated geomorphometric parameter technique encompassing proximity and texture values provides a more accurate representation of glaciers in the Greater Caucasus. Future research might combine elements of this methodology with the addition of plan and profile curvature and perhaps the thermal bands to increase the classification of debris covered glaciers, as previously suggested (e.g. Buchroithner and Bolch, 2007; Shukla et al., 2010b; Bolch et al., 2007).

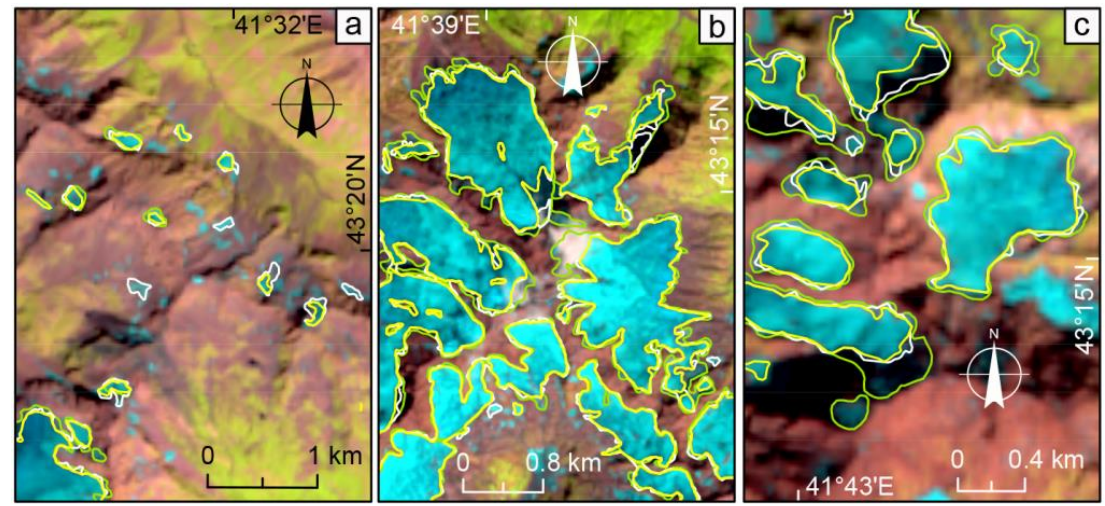

Manual Ratio 4/6 Integrating geomorphometric parameters

Figure 5. Comparison of semi-automated results for Landsat 8 OLI imagery 23/08/13. (a) Misidentification by integrating geomorphometric parameters method and 4/6 ratio compared to manual delineations (western Greater Caucasus); (b) Comparison in area with clouds; (c) Comparison of shadowed areas.

\subsection{SDC assessment using manual extents compared to Red/Mid-IR ratio methodology}

In light of the deficiences in the other methods, we decided to use the simple subtraction: SDC = Manual minus semi-automated extent areas to assess the SDC. We found SDC area 
Earth Syst. Sci. Data Discuss., https://doi.org/10.5194/essd-2017-96

Manuscript under review for journal Earth Syst. Sci. Data

Discussion started: 8 September 2017

(c) Author(s) 2017. CC BY 4.0 License.

increases for the whole Greater Caucasus in the 1986-2000-2014 period, despite the total glacier area reduction. On the northern macroslope of the western Greater Caucasus, debris cover area increased from $5.0 \%-7.1 \%-26.1 \%$, while on the southern macroslope these increased from 2.0\%-3.4\%-11.5\%; the SDC glacier areas and numbers are shown in Table 2 and Fig. 6.

Table 2. The Greater Caucasus SDC area and bare ice area change in 1986, 2000 and 2014 by macroslopes and sections.

\begin{tabular}{|c|c|c|c|c|c|c|c|c|c|c|c|c|c|}
\hline \multicolumn{2}{|c|}{ Section and river basin } & \multicolumn{4}{|c|}{ Landsat 5, 1985/86 } & \multicolumn{4}{|c|}{ Landsat 7, 2000} & \multicolumn{4}{|c|}{ Landsat 8, 2013/14. SPOT 2016} \\
\hline \multirow[b]{2}{*}{ Western Caucasus } & \multirow{2}{*}{$\begin{array}{r}\text { Total } \\
\text { glacier } \\
\text { number }\end{array}$} & \multirow{2}{*}{$\begin{array}{r}\text { Bare ice, } \\
\mathrm{km}^{2}\end{array}$} & \multicolumn{3}{|c|}{ Debris cover } & \multirow{2}{*}{$\begin{array}{r}\text { Bare ice, } \\
\mathrm{km}^{2}\end{array}$} & \multicolumn{3}{|c|}{ Debris cover } & \multirow{2}{*}{$\begin{array}{r}\text { Bare ice } \\
\mathrm{km}^{2}\end{array}$} & \multicolumn{3}{|c|}{ Debris cover } \\
\hline & & & $\begin{array}{l}\text { Glacier } \\
\text { number }\end{array}$ & $\mathrm{km}^{2}$ & $\% *$ & & $\begin{array}{l}\text { Glacier } \\
\text { number }\end{array}$ & $\mathrm{km}^{2}$ & $\%$ & & $\begin{array}{l}\text { Glacier } \\
\text { number }\end{array}$ & $\mathrm{km}^{2}$ & $\%$ \\
\hline $\begin{array}{r}\text { Northern macroslope } \\
\text { (Kuban) }\end{array}$ & 145 & $87.1 \pm 1.9$ & 15 & $4.6 \pm 0.11$ & 5.0 & $80.8 \pm 1.8$ & 21 & $6.2 \pm 0.13$ & 7.1 & $57.9 \pm 1.9$ & 33 & $20.4 \pm 0.66$ & 26.1 \\
\hline $\begin{array}{r}\text { Southern macroslope } \\
\text { (Kodori) }\end{array}$ & 78 & $34.8 \pm 0.9$ & 1 & $0.7 \pm 0.01$ & 2.0 & $31.7 \pm 0.8$ & 1 & $1.1 \pm 0.027$ & 3.4 & $23.1 \pm 0.7$ & 3 & $3.0 \pm 0.09$ & 11.5 \\
\hline \multicolumn{14}{|l|}{ Central Caucasus } \\
\hline $\begin{array}{r}\text { Northern macroslope } \\
\text { (Baksan, Chegem, } \\
\text { Cherek) }\end{array}$ & 173 & $194.7 \pm 4.2$ & 28 & $16.3 \pm 0.35$ & 7.7 & $184.5 \pm 4.2$ & 37 & $18.7 \pm 0.42$ & 9.2 & $161.9 \pm 4.1$ & 42 & $23.4 \pm 0.59$ & 12.6 \\
\hline $\begin{array}{r}\text { Southern macroslope } \\
\text { (Enguri) }\end{array}$ & 112 & $168.1 \pm 2.9$ & 15 & $10.7 \pm 0.18$ & 6.0 & $160.5 \pm 2.9$ & 15 & $10.8 \pm 0.19$ & 6.3 & $139.4 \pm 2.7$ & 17 & $10.4 \pm 0.20$ & 6.9 \\
\hline \multicolumn{14}{|l|}{ Eastern Caucasus } \\
\hline $\begin{array}{r}\text { Northern macroslope } \\
\text { (Tergi headwaters, } \\
\text { Sunja Right } \\
\text { tributaries, Sulak) }\end{array}$ & 130 & $35.4 \pm 1.5$ & 54 & $13.7 \pm 0.58$ & 27.9 & $27.2 \pm 1.1$ & 56 & $14.1 \pm 0.57$ & 34.1 & $16.3 \pm 0.8$ & 59 & $15.8 \pm 0.77$ & 49.2 \\
\hline Elbrus massif & 21 & $123.08 \pm 6.56$ & 9 & $2.30 \pm 1.7$ & 1.86 & $117.19 \pm 4.3$ & 13 & $3.70 \pm 1.0$ & 3.15 & $112.4 \pm 3.8$ & 18 & $5.98 \pm 1.5$ & 5.54 \\
\hline
\end{tabular}

$* \%$ of the total glacier area.

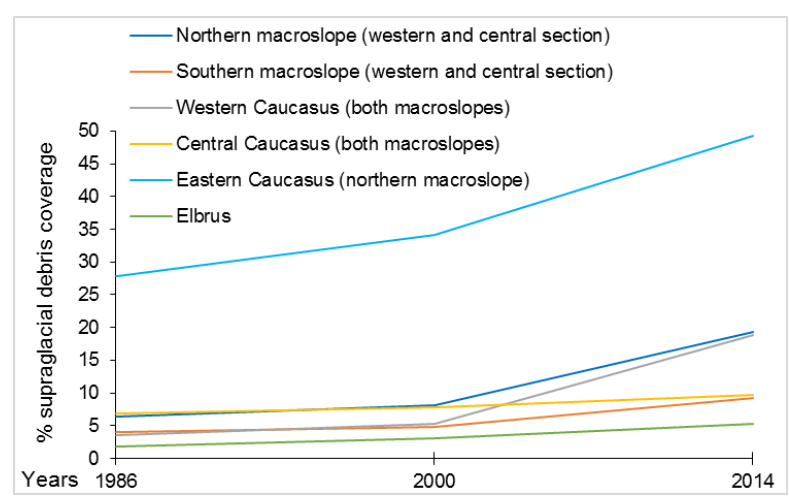

Figure 6. The Greater Caucasus SDC area increase in 1986, 2000 and 2014 by macroslopes and sections.

The central Greater Caucasus contained the largest SDC, but with lower percentage increase than the western and eastern sections over the last 30 years. On the northern macroslope, SDC 15 area increased from $7.7 \%-9.2 \%-12.6 \%$, and in the southern from $6.0 \%-6.3 \%-6.9 \%$ for the 19862000-2014 period. 
The eastern Greater Caucasus is characterized with fewer glaciers but represents the largest percentage of debris cover and rock glaciers. Over the last 30 years, SDC increased from 27.9\%$34.1 \%-49.2 \%$.

Overall, for both macroslopes on the western and central Greater Caucasus, SDC area increased from 5.2\%-6.5\%-14.3\% over the 1986-2000-2014 period (except the Elbrus). These results correlate with detailed field measurement of the Djankuat Glacier (e.g. Popovnin et al., 2015), where field investigation confirms that SDC increased from $7 \%$ to $13 \%$ between 1984 2010.

The eastern Greater Caucasus and Elbrus massif are considered a separate micro-region as a result of glacier types and rock structures. In the eastern Greater Caucasus some river basins are built on Jurassic sedimentary rocks, which suffer consistent denudation, detrimental to glacier preservation (Gobejishvili et al., 2011). The Elbrus massif contained the least debris cover in the whole investigated area, where the debris cover increased from 1.86\%-3.15\%-5.54\%.

SDC was greatest in the glacier area classes 1.0-5.0 and 5.0-10.0 $\mathrm{km}^{2}$ for both northern and southern macroslopes (Fig. 7).

One of the reasons why northern slopes are characterized with more debris than southern slopes could be associated not only with slope aspect, but also with lower slope inclination. Total glacier surface area on the southern slope includes $54.5 \%$ which are inclined $10-25^{\circ}$, while the northern has only $46.6 \%$ (Fig. 8). If local surface slope is too high, debris usually slides farther down until a gentler slope allows accumulation (Paul et al., 2004).

Another reason debris cover occurs more on the northern slope than the southern, may be that the northern slopes are longer as well as more gradual than the southern. Most valley glacier tongues in the north are longer and at lower altitudes than the southern glaciers. But there are some areas where the northern slope is shorter and steeper, and here, the glaciers of the southern macroslope are characterized with relatively more debris. An example is Georgia's largest glacier Lekhziri and its northern counterparts (with the exception of the Bashkara Glacier) (Fig. 9).

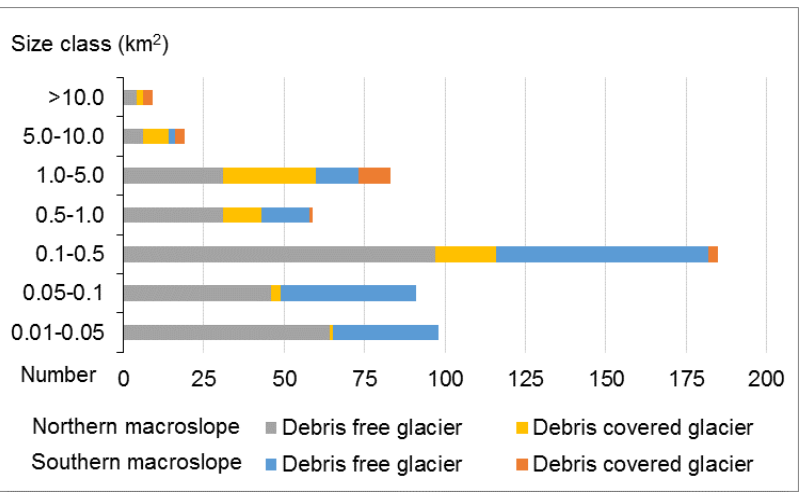

Figure 7. The Greater Caucasus glacier size classes with debris covered and debris free glaciers distributions for northern and southern macroslopes. 


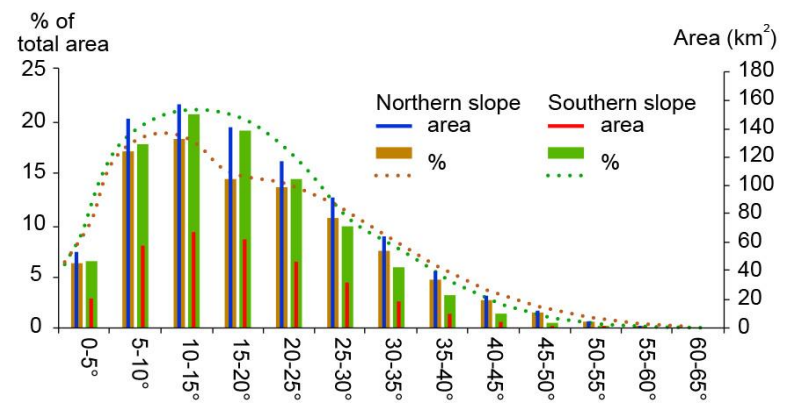

Figure 8. Greater Caucasus total glacier surface inclination for northern and southern macroslopes based on ASTER GDEM, v2 (2011).

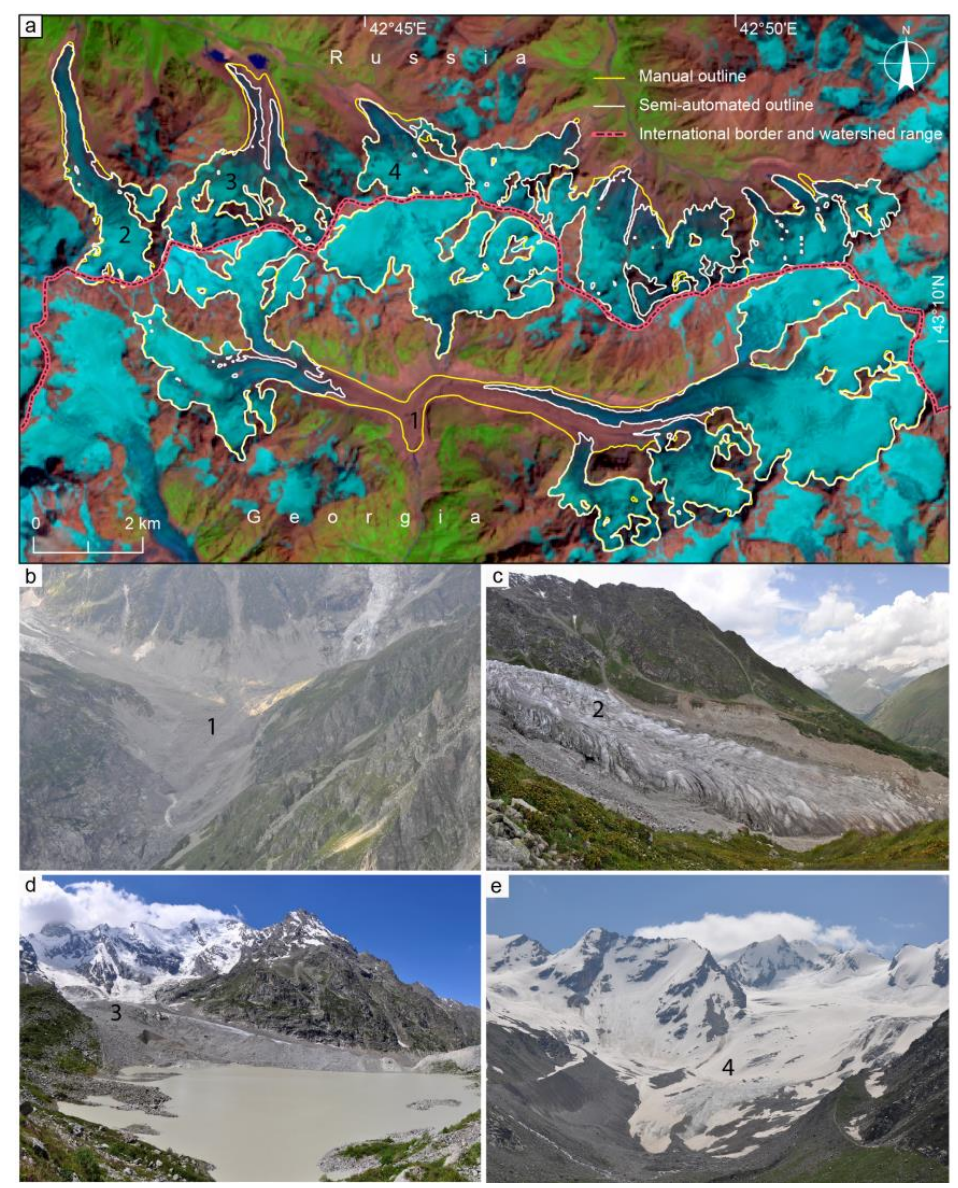

Figure 9. (a) Manual and semi-automatic outlines comparison and SDC assessment for the southern (Lekhziri, a1) and northern (Kashkatash a2, Bashkara a3 and Djankuat a4) glaciers (Landsat 8 OLI 03/08/2014) (b) Lekhziri Glacier tongue in 2011; (c) Kashkatash Glacier tongue in 2014; (d) Bashkara Glacier tongue in 2014; (e) Djankuat Glacier in 2014. (All photos by L.G. Tielidze, central Greater Caucasus). 
The Little Ice Age (LIA) moraine can affect the SDC increase on the glacier tongue, as debris often falls from lateral moraines onto the glacier surface (Popovnin et al., 2015; Pratar et al., 2015). The LIA moraines for the northern Caucasus valley glaciers are 2-3 times longer (e.g. Bezingi, Dikh-kotiu-bugoisy, Karaugom, etc.) and more well preserved than the southern.

Compared to the western and eastern sections, a small percentage increase of the SDC on the central section can be attributed to its high elevation and steep slopes. In the eastern Caucasus, a large percentage of the debris cover is a result of the geology, as some parts of the eastern Caucasus are Jurassic sedimentary rocks (Gobejishvili et al., 2011; Tielidze, 2017a), and therefore the process of mechanical denudation is more intense. Consequently, this region is characterized by rock glaciers which are not typical for the central and western Caucasus (Fig. 10).

We have observed in multiple locations, the process of up-glacier migration of debris cover, as a response to glacier retreat and thinning, as described by Stokes et al. (2017) and defined as 'backwasting' by Benn and Evans (1998). Ablation is more intense where debris cover is thin towards its up-glacier limit.

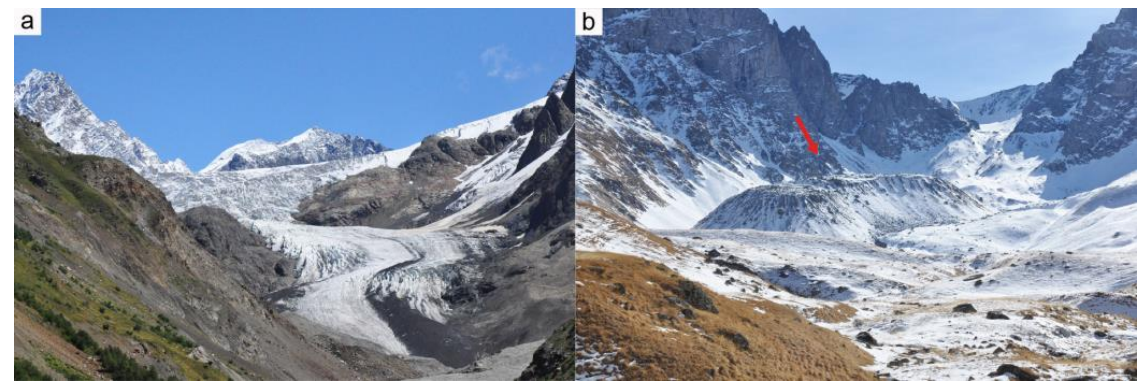

Figure 10. (a) Kvitlodi Glacier in 2011, a typical glacier for the central Greater Caucasus, with less SDC area and more bare ice; (b) Chaukhi Rock Glacier in 2014 covered by full debris, a typical glacier for the eastern Greater Caucasus (photos by L.G. Tielidze).

Glacier thinning and a warming climate can lead to permafrost melting and slope instability at higher altitudes (Stokes et al., 2007). The rock avalanches of the Djankuat (2001, 2003), Suatisi (2007, 2010) and Devdoraki (2017) glaciers, have dramatically increased SDC (Fig. 11).

By definition glaciers for the purpose of glacier mapping from space, include all debriscovered parts. A stagnant ice mass that is still in contact with a glacier is part of the glacier, even if it supports an old growth forest (Racoviteanu et al., 2009). In the case of Elbruz, GPR measurements showed that a substantial amount of ice (20-40 m) may be present under debris cover on the eastern slope even though high resolution imagery and oblique photograph do not give any clear additional evidence (Fig. 12). We have identified a more than doubling of debris covered areas for Elbrus glaciers 1986-2014 (Fig. 13), although the total uncertainty is comparable to the obtained relative changes. Comparison with the semi-automated methods shows that debris cover may be considerably underestimated. These glaciers are characterized by 
high rates of retreat and great expansion in proglacial lake numbers and area (Petrakov et al., 2007). A more detailed GPR survey may help to accurately identify debris covered glacier boundaries in this area.

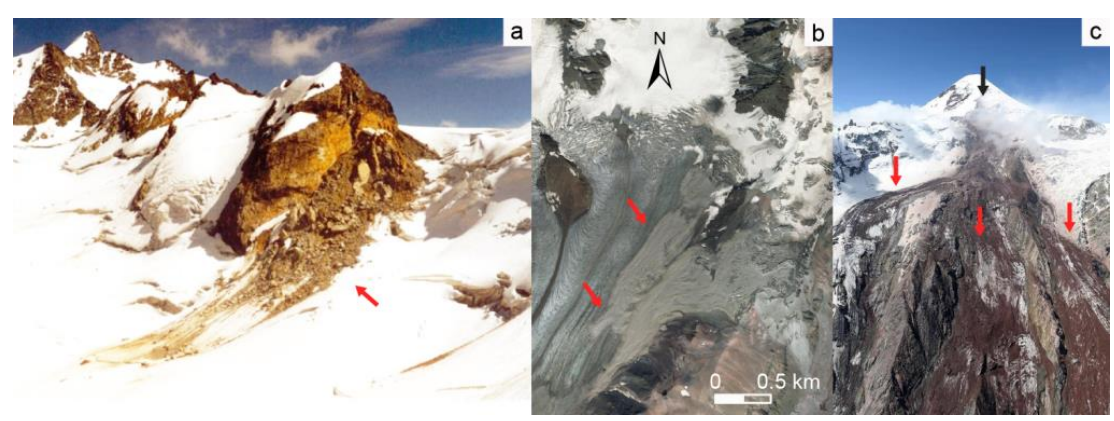

Figure 11. (a) Djankuat (2001), (b) Suatisi $(2007,2010)$ and (c) Devdoraki (2017) glacier rock falls. Red arrows show the flow of the rock-ice avalanche. The black arrow shows the center of genesis of the rockice avalanche (4600 $\mathrm{m}$ asl).

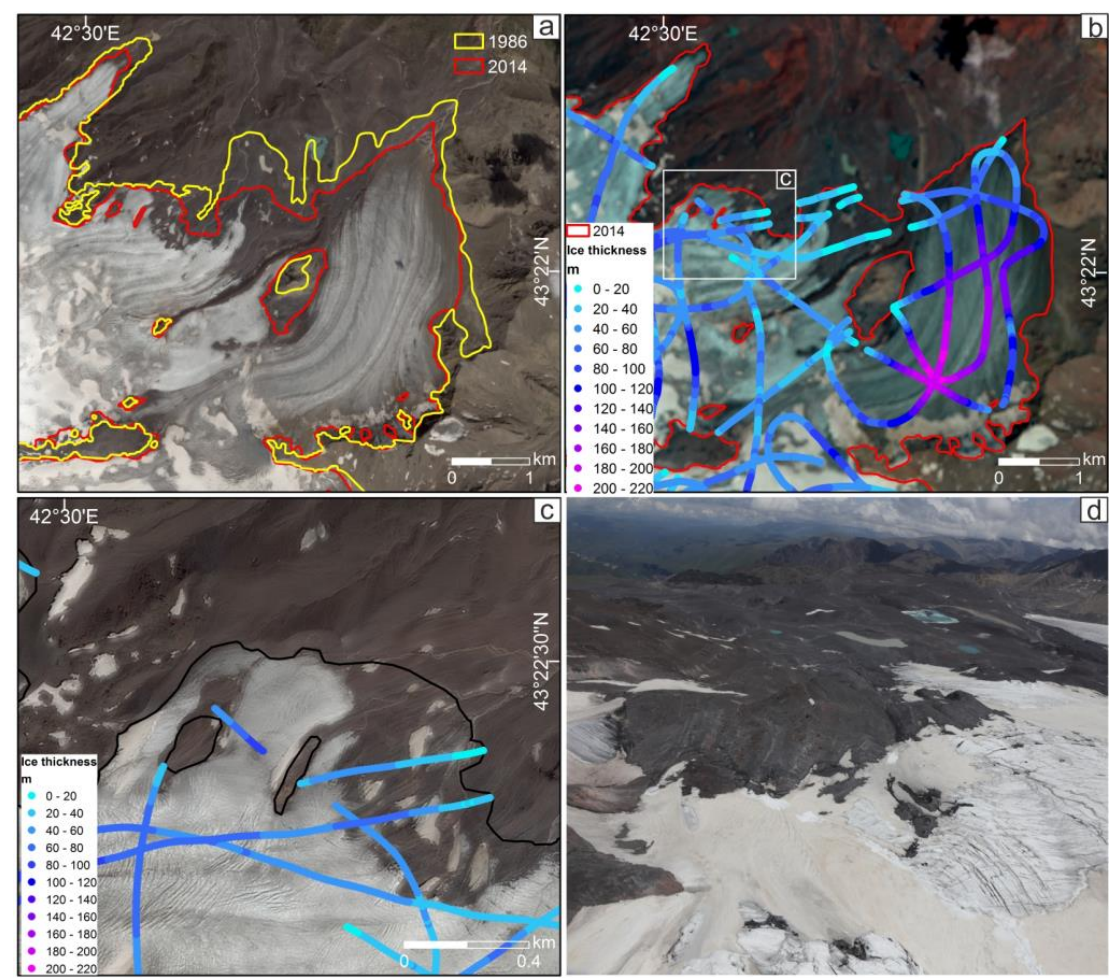

Figure 12. Glaciers of the eastern slope of Elbrus. a) glacier outlines of 1986 and 2014, SPOT-7 image used as a background; b) Ice thickness profiles obtained during aerial GPR survey in 2014, Landsat 8 image of 2014; c) glacier outlines and ice thickness profiles with SPOT-7 high resolution image. d) oblique photograph of the glacier tongues taken from helicopter in 2014 (photo by I.I. Lavrentiev). 


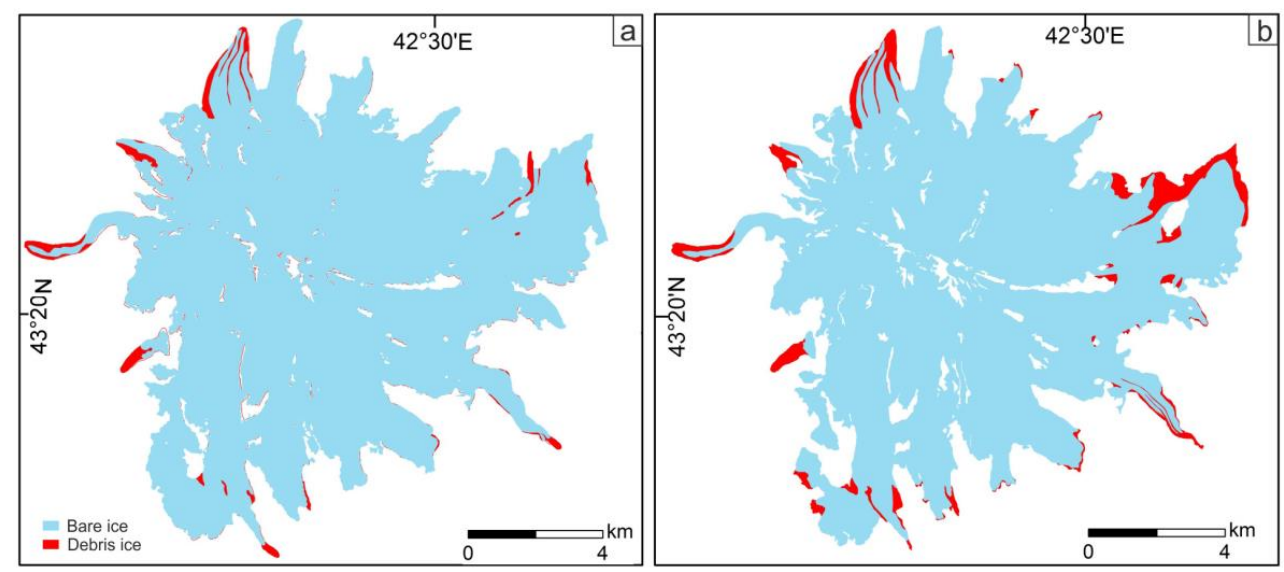

Figure 13. Debris cover increase on the Elbrus massif from 1986 (a) to 2014 (b).

\section{Conclusions}

Using Landsat and SPOT imagery 1985/86-2000-2013/14/16, along with the ASTER GDEM (2011), we have assessed SCD change over the last 30 years in the Greater Caucasus region. We measured total glacier area decrease and SDC area increase for all sections and slopes in the investigated region. From 559 selected glaciers, the western and central Greater Caucasus region experienced SDC area increase at an average annual rate of $0.30 \% \mathrm{yr}^{+1}$, while the eastern Caucasus region increased by $0.71 \% \mathrm{yr}^{+1}$. The Elbrus massif had the lowest SDC increase in the whole investigated region at $0.11 \% \mathrm{yr}^{+1}$.

As SDC continues to increase in the Greater Caucasus region, it is vital to continue monitoring supraglacial and periglacial debris cover with proglacial lakes against potential glacier-related hazards, within an overall environment of deglaciation. Future work should focus on using high resolution aerial/satellite imagery and more detailed field measurements (e.g. debris thickness, GPR, etc.) to reduce uncertainties connected with debris cover assessment and glacier mapping accuracy in this region.

\section{References}

Alifu, H., Tateishi, R., and Johnson, B.: A new band ratio technique for mapping debris-covered glaciers using Landsat imagery and a digital elevation model, International Journal of Remote Sensing, Vol. 36, No. 8, 2063-2075, doi.org/10.1080/2150704X.2015.1034886, 2015.

Andreassen, L., Paul, F., Kaab, A., and Hausberg, J.: Landsat-derived glacier inventory for Jotunheimen, Norway, and deduced glacier changes since the 1930s. The Cryosphere, 2(2), 131-145, 2008.

Baraer, M., Mark, B. G., McKenzie, J. M., Condom, T., Bury, J., Huh, K. I., Portocarrero, C., Gomez, J., and Rathay, S.: Glacier recession and water resources in Peru's Cordillera Blanca. Journal of Glaciology, 58, 134-150, 2012. 
Benn, D. I., and Evans, D. J. A.: Glaciers and Glaciation, Arnold, London, 1998.

Benn, D., Bolch, T., Hands, K., Gulley, J., Luckman, A., Nicholson, L., Quincey, D., Thompson, S., Toumi, R., and Wiseman, S.: Response of debris-covered glaciers in the Mount Everest region to recent warming, and implications for outburst flood hazards. Earth-Science Reviews, 114, 156-174, 2012.

Bhambri, R., Bolch, T., and Chaujar, R. K.: "Mapping of Debris-Covered Glaciers in the Garhwal Himalayas Using ASTER Dems and Thermal Data." International Journal of Remote Sensing 32 (23): 8095-8119. doi:10.1080/01431161.2010.532821, 2011.

Biddle, D. J.: Mapping debris-covered glaciers in the Cordillera Blanca, Peru: an object-based image analysis approach, doi.org/10.18297/etd/2220, 2015.

Bishop, M. P., Hickman, B. L., and Shroder J. F.: High Resolution Satellite Imagery and Neural Networks for Information Extraction in a Complex Mountain Environment. Geocarto International 14 (2): 17-26. doi:10.1080/10106049908542100, 1999.

Bishop, M. P., Bonk, R., Kamp, U., and Shroder, J. F.: Terrain Analysis and Data Modeling for Alpine Glacier Mapping. Polar Geography 25: 182-201. doi:10.1080/10889370109377712, 2001.

Bolch, T., and Kamp, U.: Glacier Mapping in High Mountains Using Dems, Landsat and ASTER Data. In Proceedings of the 8th International Symposium on High Mountain Remote Sensing Cartography, March 20-27, 2005, La Paz, 13-24. Graz: Grazer Schriften de Georaphie und Raumforschung, 2006.

Bolch, T., Buchroithner, M. F., Kunert, A., and Kamp, U.: Automated delineation of debriscovered glaciers based on ASTER data. In Geoinformation in Europe. proceedings of the 27th EARSeL Symposium (pp. 4-6), 2007.

Bolch, T., Menounos, B., and Wheate, R.: Landsat based inventory of glaciers in western Canada, 1985-2005, Remote Sens. Environ., 114, 127-137, doi:10.1016/j.rse.2009.08.015, 2010.

Brock, B. W., Mihalcea, C., Kirkbride, M. P., Diolaiuti, G., Cutler, M. E. J., and Smiraglia, C.: Meteorology and surface energy fluxes in the 2005- 2007 ablation seasons at the Miage debris-covered glacier, Mont Blanc Massif, Italian Alps. Journal of Geophysical Research: Atmospheres, 115, 2010.

Buchroithner, M. F. and Bolch, T.: An automated method to delineate the ice extension of the debris-covered glaciers at Mt. Everest based on ASTER imagery. 9th International Symposium on High Mountain Remote Sensing Cartography, 2007.

DeBeer, C. M. and Sharp, M. J.: Recent changes in glacier area and volume within the southern Canadian Cordillera, Ann. Glaciol., 46, 215-221, 2007.

Farinotti, D., and 36 others: How accurate are estimates of glacier ice thickness? Results from ITMIX, the Ice Thickness Models Intercomparison eXperiment, The Cryosphere, 11, 949-970, doi.org/10.5194/tc-11-949-2017, 2017 
Foster, L. A., Brock, B. W., Cutler, M. E. J., and Diotri, F.: A physically based method for estimating supraglacial debris thickness from thermal band remote-sensing data. J Glaciol, 58: 677-691, 2012.

Frey, H., Paul, F., and Strozzi, T.: Compilation of a glacier inventory for the western Himalayas from satellite data: methods, challenges, and results, Remote Sens. Environ., 124, 832-843, 2012.

Gobejishvili, R., Lomidze, N., and Tielidze, L.: Late Pleistocene (Wurmian) glaciations of the Caucasus, in: Quaternary Glaciations: Extent and Chronology, edited by: Ehlers, J., Gibbard, P. L., and Hughes, P. D., Elsevier, Amsterdam, 141-147, doi:10.1016/B978-0-444-534477.00012-X, 2011.

Granshaw, F., D. and Fountain, A. G.: Glacier change (1958-1998) in the North Cascades National Park Complex, Washington, USA. J. Glaciol., 52(177), 251-256, doi: 10.3189/172756506781828782, 2006.

Guo, W., Liu S., Wei, J., and Bao, W.: The 2008/09 surge of central Yulinchuan glacier, northern Tibetan Plateau, as monitored by remote sensing. Ann. Glaciol., 54(63), 299-310, doi:10.3189/2013AoG63A495, 2013.

Guo, W., and 11 others: The second Chinese glacier inventory: data, methods and results. Journal of Glaciology, Vol. 61, No. 226, doi: 10.3189/2015JoG14J209, 2015.

Haeberli, W. R., Frauenfelder, R., Hoelzle, M., and Maisch, M.: On rates and acceleration trends of global glacier mass changes. Geografiska Annaler. Series A. Physical Geography, 81A,585-595, 1999.

Kaldani, L., and Salukvadze M.: Tovlis Zvavebi Saqartveloshi (Snow Avalanches in Georgia). Monograph, Technical University of Georgia, Institute of Hydrometeorology, pp. 167. 2015 (in Georgian).

Kutuzov, S. S., Lavrentiev, I. I., Vasilenko, E. V., Macheret, Y. Y., Petrakov, D. A., and Popov, G. V.: Otsenka obiema lednikov Bolshogo Kavkaza po dannym radiozondirovania i modelirovania (Estimation of the Greater Caucasus glaciers volume, using radio-echo sounding data and modelling), Kriosfera Zemli (Earth Cryosphere), 1, 78-88, 2015 (in Russian with English summary).

Lambrecht, A., Mayer, C., Hagg, W., Popovnin, V., Rezepkin, A., Lomidze, N., and Svanadze, D.: A comparison of glacier melt on debris-covered glaciers in the northern and southern Caucasus, The Cryosphere, 5, 525-538, doi:10.5194/tc-5-525-2011, 2011.

Oerlemans, J.: Extracting climate signals from 169 glacier records. Science, 308, 675-677, 2005.

Paul, F.: Evaluation of different methods for glacier mapping using Landsat TM. Dresden, Proceedings of EARSeL-SIG-Workshop Land Ice and Snow, 2000.

Paul, F., Kaab, A., Maisch, M., Kellenberger, T., and Haeberli, W.: The New RemoteSensingDerived Swiss Glacier Inventory: I. Methods. Annals of Glaciology 34 (1): 355-361, doi:10.3189/172756402781817941, 2002. 
Paul, F., Huggel, C., and Kaab, A.: Combining Satellite Multispectral Image Data and a Digital Elevation Model for Mapping Debris-Covered Glaciers. Remote Sensing of Environment 89: 510-518. doi:10.1016/j.rse.2003.11.007, 2004.

Paul, F., and Kaab, A.: Perspectives on the production of a glacier inventory from multispectral satellite data in Arctic Canada: Cumberland Peninsula, Baffin Island. Annals of Glaciology, 42, 59-66, 2005.

Paul, F., Kaab, A., and Haeberli, W.: Recent glacier changes in the Alps observed by satellite: Consequences for future monitoring strategies. Global and Planetary Change, 56, 111-122, 2007.

Paul, F., and Andreassen, L. M.: A new glacier inventory for the Svartisen region, Norway, from Landsat ETM+ data: challenges and change assessment. J. Glaciol., 55(192), 607-618, doi:10.3189/002214309789471003, 2009.

Paul, F., Barrand, N., Baumann, S., Berthier, E., Bolch, T., Casey, K., Frey, H., Joshi, S., Konovalov, V., Le Bris, R., Molg, N., Nosenko, G., Nuth, C., Pope, A., Racoviteanu, A., Rastner, P., Raup, B., Scharrer, K., Steffen, S., and Winsvold, S.: On the accuracy of glacier outlines derived from remote-sensing data, Ann. Glaciol., 54, 171-182, doi:10.3189/2013AoG63A296, 2013.

Paul, F., Winsvold, S. H., Kääb, A., Nagler, T. and Schwaizer, G.: Glacier Remote Sensing Using Sentinel-2. Part II: Mapping Glacier Extents and Surface Facies, and Comparison to Landsat 8. Remote Sensing, 8(7), p. 575, 2016.

Petrakov, D. A., Krylenko, I. V., Chernomorets, S. S., Tutubalina, O. V., Krylenko, I. N., and Shakhmina, M. S.: Debris flow hazard of glacial lakes in the Central Caucasus. Debris-Flow Hazards Mitigation: Mechanics, Prediction, and Assessment, Chen \& Major, eds. Millpress, Netherlands, 2007.

Pfeffer, W. T., and 19 others: The Randolph Glacier Inventory: a globally complete inventory of glaciers. J. Glaciol., 60(221), 537-552. doi: 10.3189/2014JoG13J176, 2014.

Popovnin, V. V., and Rozova, A.: Influence of sub-debris thawing on ablation and runoff of the Djankuat Glacier in the Caucasus. Nord. Hydrol., 33, 75-94., 2002.

Popovnin, V. V., Rezepkin, A. A., and Tielidze, L. G.: Superficial moraine expansion on the Djankuat Glacier snout over the direct glaciological monitoring period, Earth Cryosphere, vol. XIX, No. 1, pp. 79-87, 2015.

Pratap, Dobhal, D. P., Mehta, M., And Bhambri, R.: Influence of debris cover and altitude on glacier surface melting: a case study on Dokriani Glacier, central Himalaya, India. Annals of Glaciology 56(70), doi:10.3189/2015AoG70A971, 2015.

Racoviteanu, A. E., Paul, F., Raup, B., Khalsa, S. J. S., and Armstrong, R.: Challenges and recommendations in mapping of glacier parameters from space: results of the 2008 Global Land Ice Measurements from Space (GLIMS) workshop, Boulder, Colorado, USA. Ann. Glaciol., 50(53), 53-69, doi:10.3189/172756410790595804, 2009. 
Racoviteanu, A., and Williams, M.W.: Decision tree and texture analysis for mapping debriscovered glaciers in the Kangchenjunga area, Eastern Himalaya. Remote sensing, 4 (10), 30783109, 2012.

Racoviteanu, A., Arnaud, Y., Williams, M.W. and Manley, W.F.: Spatial patterns in glacier characteristics and area changes from 1962 to 2006 in the Kanchenjunga-Sikkim area, eastern Himalaya. The Cryosphere, 9, 505-523, 2014.

Raina, V. K., and Srivastava, D.: Glacier Atlas of India, Geological Society of India, Bangalore, 2008.

Ranzi, R., Grossi, G., Iacovelli, L., and Taschner, S.: Use of Multispectral ASTER Images for Mapping Debris-Covered Glaciers within the GLIMS Project. Proceedings of the IEEE International Geoscience and Remote Sensing Symposium, IGARSS ‘04 2: 1144-1147, 2004.

Raup, B., and 11 others: Remote sensing and GIS technology in the global land ice measurements from space (GLIMS) project. Comput. Geosci., 33(1), 104-125, doi:10.1016/j.cageo.2006.05.015, 2007.

Scherler, D., Bookhagen, B., and Strecker, M. R.: Spatially variable response of Himalayan glaciers to climate change affected by debris cover, Nat. Geosci., 4, 156-159, doi:10.1038/ngeo1068, 2011.

Shahgedanova, M., Nosenko, G., Kutuzov, S., Rototaeva, O., and Khromova, T.: Deglaciation of the Caucasus Mountains, Russia/Georgia, in the 21st century observed with ASTER satellite imagery and aerial photography, The Cryosphere, 8, 2367-2379, doi:10.5194/tc-8-2367-2014, 2014.

Shukla, A., Gupta, R. P., and Arora, M. K.: Delineation of debris-covered glacier boundaries using optical and thermal remote sensing data. Remote Sensing Letters, 1, 11-17, 2010a.

Shukla, A., Arora, M. K., and Gupta, R.P.: Synergistic approach for mapping debris-covered glaciers using optical-thermal remote sensing data with inputs from geomorphometric parameters. Remote Sensing of Environment, 114, (7),1378-1387, 2010b.

Solomina, O., Bushueva, I., Dolgova, E., Jomelli, V., Alexandrin, M., Mikhalenko, V., and Matskovsky, V.: Glacier variations in the Northern Caucasus compared to climatic reconstructions over the past millennium, Global and Planetary Change., 140, 28-58, .doi.org/10.1016/j.gloplacha.2016.02.008, 2016.

Stokes, C. R., Gurney, S. D., Popovnin, V., and Shahgedanova M.: Late-20th-century changes in glacier extent in the Caucasus Mountains, Russia/Georgia, J. Glaciol., 52, 99-109, 2006.

Stokes, C. R., Popovnin, V. V., Aleynikov, A., and Shahgedanova, M.: Recent glacier retreat in the Caucasus Mountains, Russia, and associated changes in supraglacial debris cover and supra/proglacial lake development, Ann. Glaciol., 46, 196-203, 2007.

Tielidze, L. G.: Glacier change over the last century, Caucasus Mountains, Georgia, observed from old topographical maps, Landsat and ASTER satellite imagery, The Cryosphere, 10, 713725, doi.org/10.5194/tc-10-713-2016, 2016. 
Tielidze, L.: The New Inventory and General Description of the Modern Glaciers. Chapter in Glaciers of Georgia, Springer, Geography of the Physical Environment, doi:10.1007/978-3319-50571-8-3, 2017a.

Tielidze, L.: Introduction. Chapter in Glaciers of Georgia, Springer, Geography of the Physical Environment, doi:10.1007/978-3-319-50571-8-1, 2017b.

Tielidze, L. G. and Wheate, R. D.: The Greater Caucasus Glacier Inventory (Russia/Georgia/Azerbaijan), The Cryosphere Discuss., doi:10.5194/tc-2017-48, in review, 2017.

Tiwari, R. K., Garg, P. K., Saini, V., and Shukla, A.: Comparisons of different methods for debris covered glacier classification. In SPIE Asia-Pacific Remote Sensing (pp. 98771K-98771K). International Society for Optics and Photonics, 2016.

Veettil, B. K.: A Remote sensing approach for monitoring debris-covered glaciers in the high altitude Karakoram Himalayas. International Journal of Geomatics and Geosciences, 2, 833841, 2012.

15 Zhang Y., Hirabayashi, Y., Fujita, K., Liu, S., and Liu, Q.: Heterogeneity in supraglacial debris thickness and its role in glacier mass changes of the Mount Gongga, Science China Earth Sciences 59, 170, doi:10.1007/s11430-015-5118-2, 2016. 